\title{
OPTIMIZATION OF BUILDING VENTILATION FOR GERDAU BEAUMONT MELTSHOP USING PHYSICAL FLUID DYNAMIC MODELING*
}

\author{
Jim Belous ${ }^{1}$ \\ Ricardo Anawate ${ }^{2}$
}

\begin{abstract}
Fluid Dynamic Modeling (FDM) was used to develop solutions how to eliminate the fugitive emissions from the meltshop building and to comply with the EPA "6\% opacity from the furnace operations" rule. Secondary Emission Control (SEC) system performance was simulated by an inverted 1:96 scale Plexiglas model of the entire meltshop, utilizing the negative buoyancy effects of saline solution in water. Test results show that with the installation of the internal partition wall which separates furnace aisle from the caster aisle, significant improvement of the SEC system is achievable, thereby avoiding large expenditure for the expanding a fume collection system capacity.
\end{abstract}

Keywords: Meltshop ventilation; FDM study; Emission control system; Fugitive emissions; Model test; Building ventilation.

1 Managing Director, Bender Corporation, Inc. 9304 Civic Center Dr. Suite \#3, Beverly Hills, CA 90210, Phone: (310) 274-7368, Email: ibelous@bendercorp.com.

2 Vice President and General Manager, Gerdau Jackson TN Mill, 801 Gerdau Drive, Jackson TN 38305, USA, Ph: (731)423-5220. 


\section{INTRODUCTION}

The purpose of the study was to determine a feasible and cost effective solution for the building ventilation in order to allow the company to reduce fugitive emissions from the meltshop and to comply with the " $6 \%$ opacity from electric arc furnace operations" regulation.

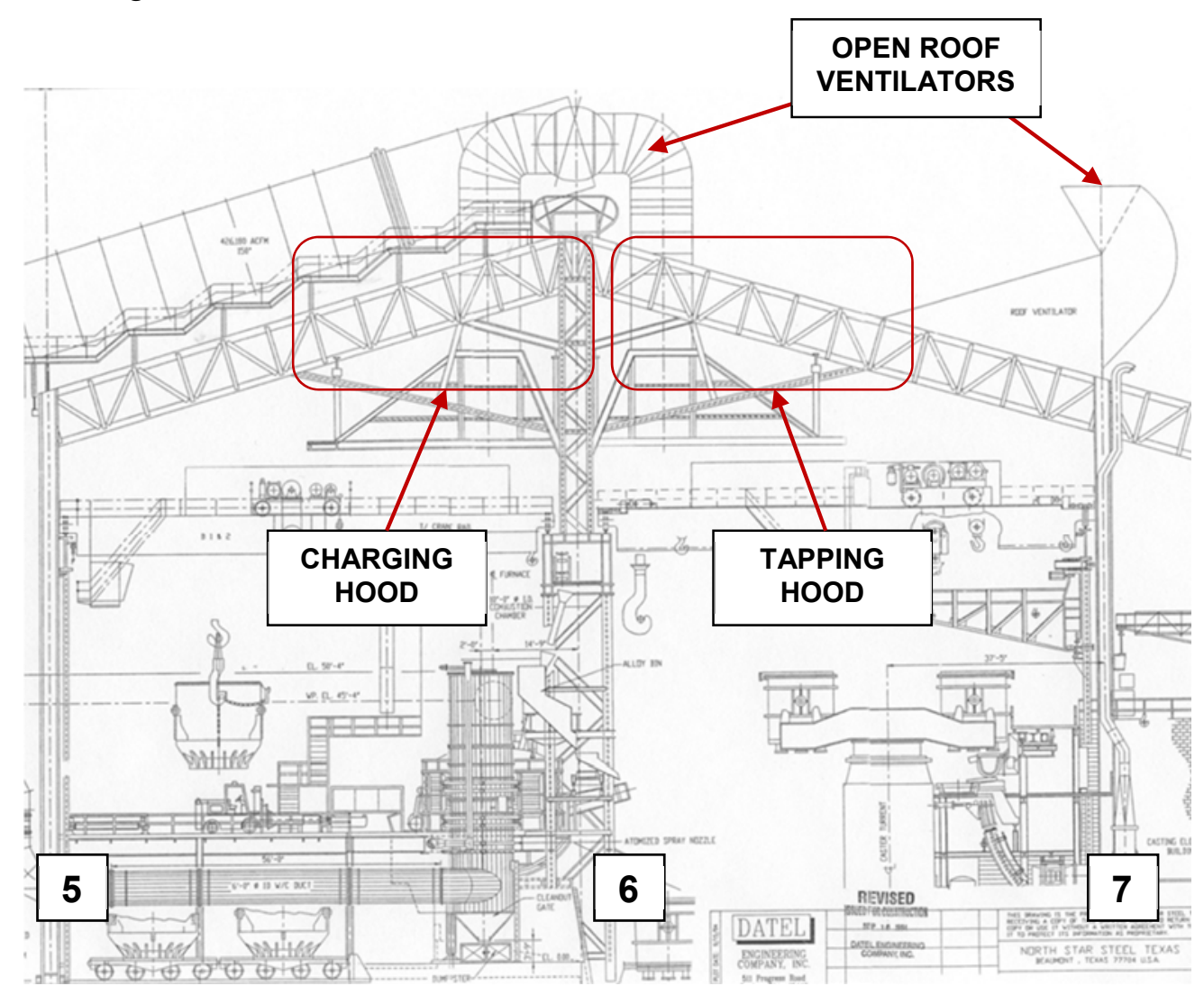

Figure 1. Meltshop cross-sectional view

The Gerdau Beaumont meltshop is an open roof type where the Secondary Emission Control (SEC) system consists of the canopy hood system dedicated to control the emissions generated during all modes of the furnace operations that are not captured with the Direct Evacuation Control (DEC) system, with the open gravity roof ventilators used for heat evacuation.

The charging and tapping canopy hoods are suspended from the building structure under the meltshop roof and are not capable of capturing the entire volume of the charging and tapping emissions. The fumes are deflected from the canopy hoods and partly escape to the outside environment through the roof ventilators at the roof ridge and above the caster and partly spread across the entire meltshop building. The emissions inside the building cool down by mixing with the ambient air inside the shop, settle at a lower elevation and form a persistent haze. 


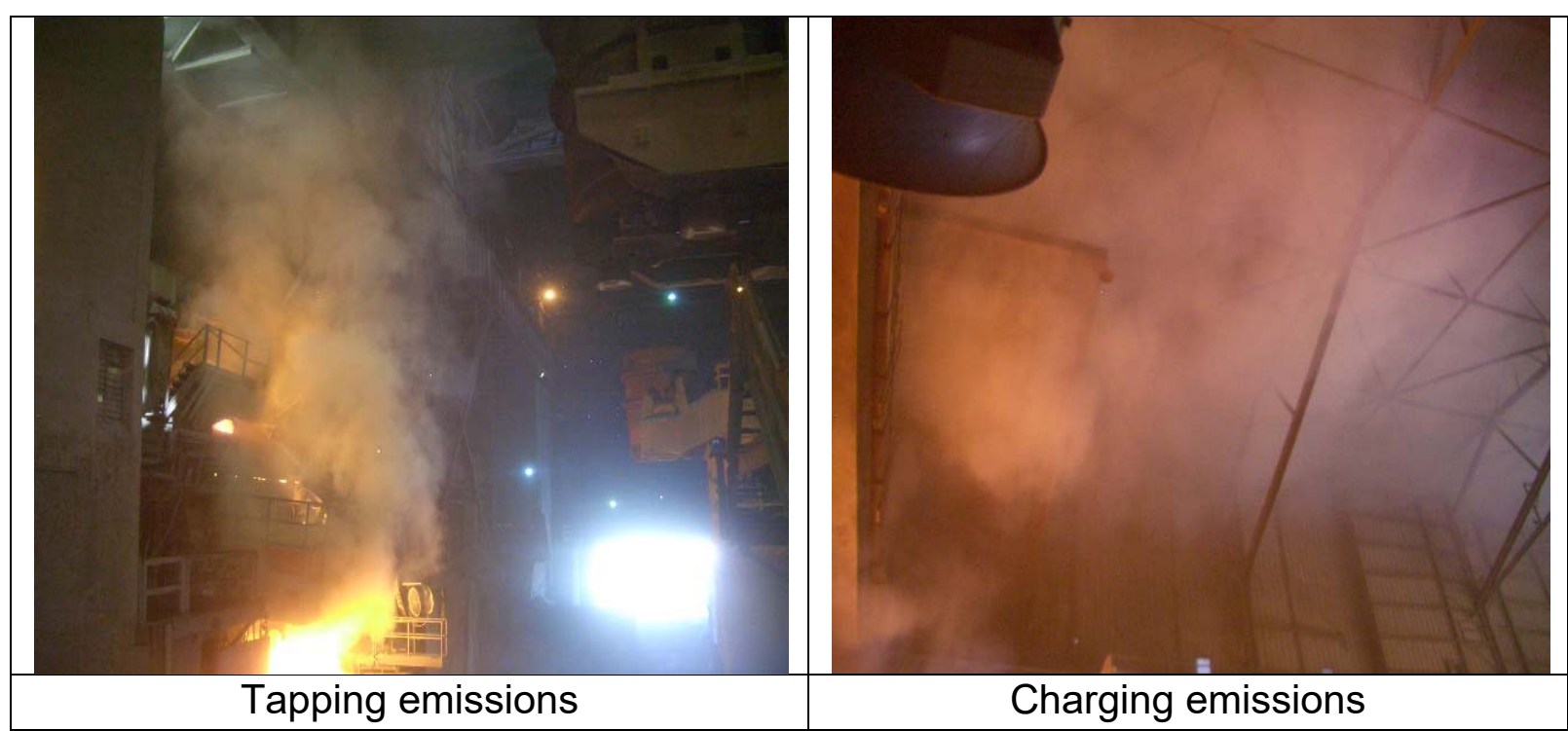

Figure 2. Meltshop conditions

Hypothetically the fugitive emissions from the building can be eliminated by closing all roof ventilators thus converting the meltshop into a closed roof type. However, in this case the capacity of the emission control system would have to be increased by more than double in order to evacuate the heat from the meltshop (see Figure 3 below), not to consider that the hot air from clean heat sources, such as ladle preheaters, caster deck operations, etc., would block the canopy hood off-takes and much colder fume emissions would be forced to reside at a lower elevation, filling the shop with fume.

A Computational Fluid Dynamic (CFD) study of the meltshop ventilation was previously conducted in order to investigate possible solutions to eliminate fugitive emissions from the building and at the same time to improve the environment inside the shop.

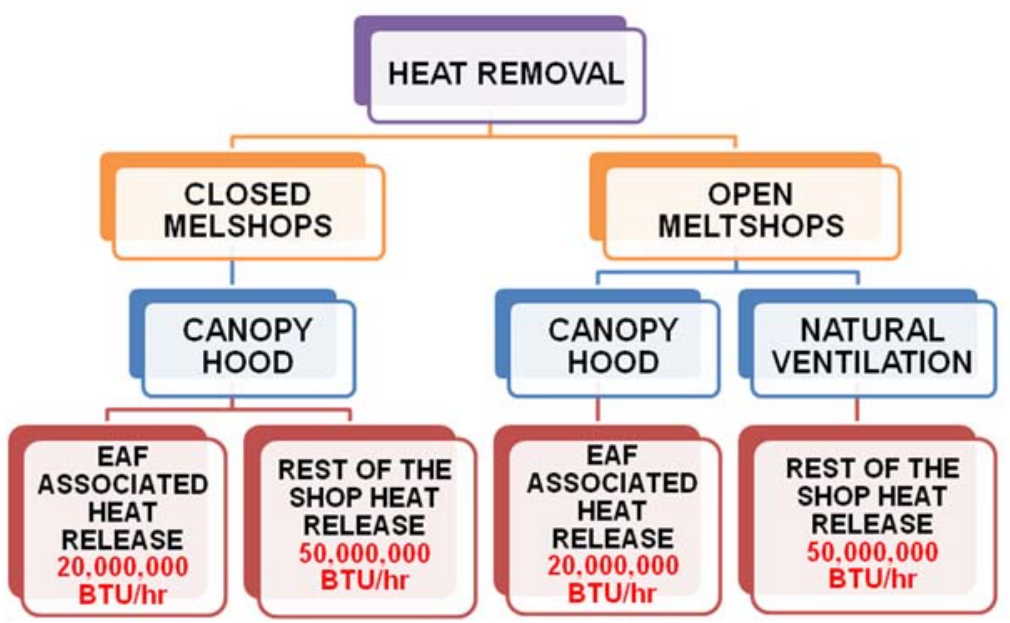

Figure 3. Heat removal from open and closed roof meltshops

The CFD study yielded the following solution:

1. Install a larger canopy hood above the furnace between column lines $\mathrm{H}$ and $\mathrm{F}$.

2. Eliminate existing partition walls above the crane runway.

3. No partition walls deemed to be necessary below crane runway. 
4. Increase the overall capacity of the emission control system from 700,000 ACFM to $1,200,000$ ACFM.

The high cost of the proposed modifications and certain doubts about the effectiveness of the concept raised concerns among the Gerdau personnel and Bender Corporation, Inc.(BCl) was asked to conduct a Physical Fluid Dynamic Model (FDM) study in order to verify the results of the CFD and, if possible, to develop an alternate solution.

\section{Fluid dynamic model (FDM) study}

The FDM study simulates the building ventilation behavior by use of the inverted scale model of the meltshop utilizing the negative buoyancy effects of the saline solution in water for heat sources representation.

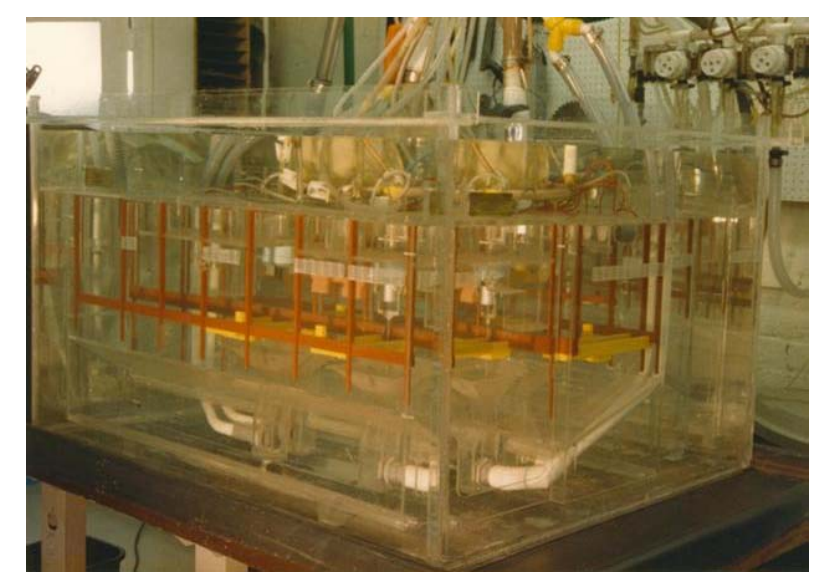

Figure 4. Inverted model in a water tank.

The FDM tests show that even with the increased capacity of the emission control system the enlarged canopy hood is capable of providing only a marginal performance benefit.

\begin{tabular}{|c|c|c|c|c|c|}
\hline \multirow{2}{*}{ 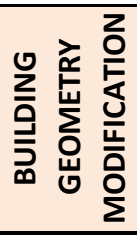 } & \multicolumn{2}{|c|}{$\begin{array}{l}\text { HOOD BETWEEN H AND F (see p. } 6 \text { ) } \\
\text { REMOVED PARTITION ABOVE RUNWAY BETWEEN H AND F } \\
\text { NO SHEETING BELOW CRANE RUNWAY } \\
\text { NORTH AND EAST ENTRY DOORS INTO CASTER AISLE CLOSED }\end{array}$} & & & \\
\hline & \multicolumn{2}{|l|}{ 15-20 MPH WIND } & & & \\
\hline \multirow{4}{*}{ 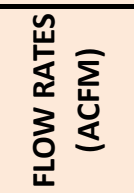 } & \multirow{2}{*}{ CHARGING/TAPPING } & CHARGING SIDE & 600000 & 600000 & 700000 \\
\hline & & TAPPING SIDE & 600000 & 600000 & 200000 \\
\hline & \multirow{2}{*}{ MELTING } & CHARGING SIDE & 525000 & 525000 & 500000 \\
\hline & & TAPPING SIDE & 525000 & 525000 & 250000 \\
\hline & & & TEST 9 & TEST 9B & TEST 10 \\
\hline
\end{tabular}

Table I. Test sequence to validate the results of the CFD modeling. 


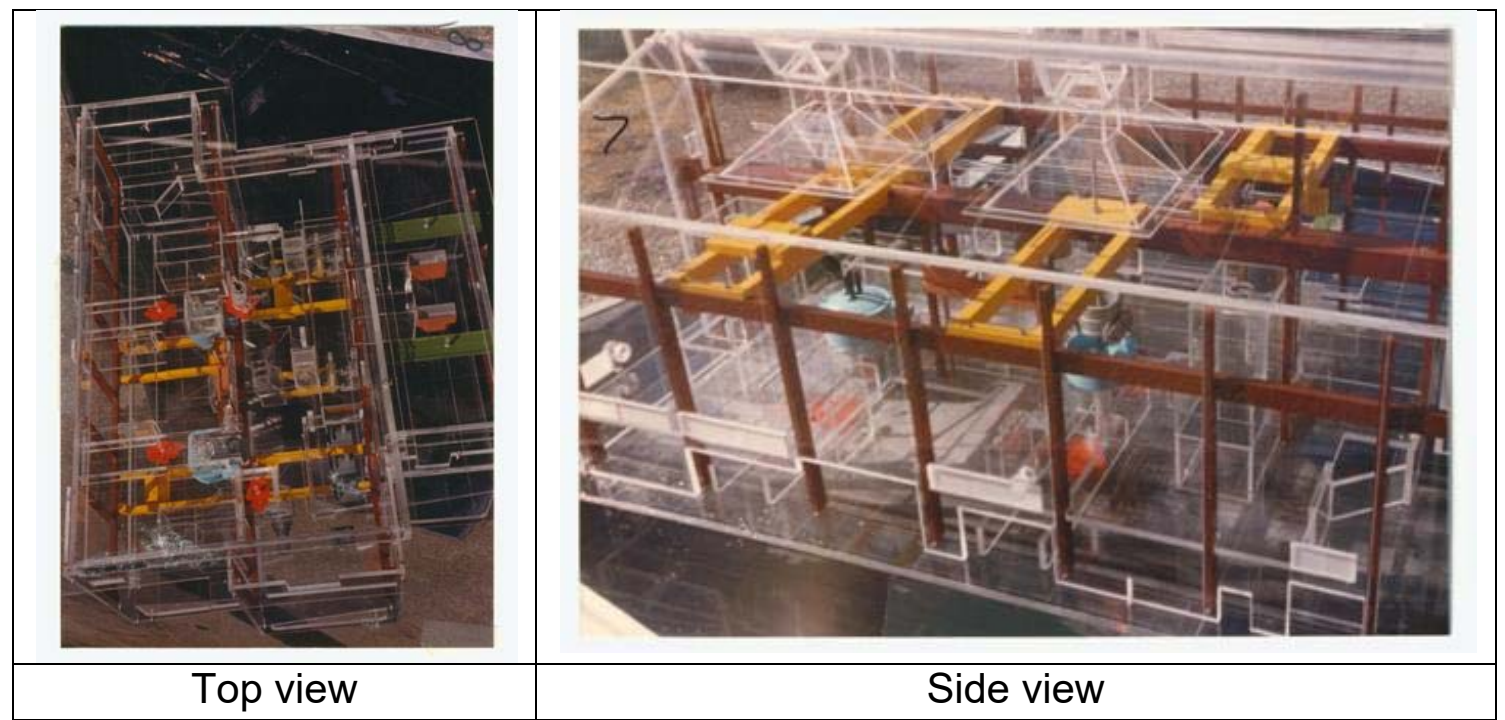

Figure 5. Finished model.

The results of Test 9, which simulates the solution developed during CFD modeling, show that the canopy hood manages to contain the melting, tapping and charging fume within the hood on the tapping side. Although the fume does not escape from the hood on the tapping side, it does escape the hood on the furnace side. The fume migrates to lower levels throughout the furnace aisle and is impossible to recapture by the canopy hood alone. Scavengers would have to be used on each side of the canopy, which would require even more exhaust capacity. Clean heat also enters the canopy hood from the caster aisle heat sources which occupies volume of the hood and further reduces the canopy hood efficiency.

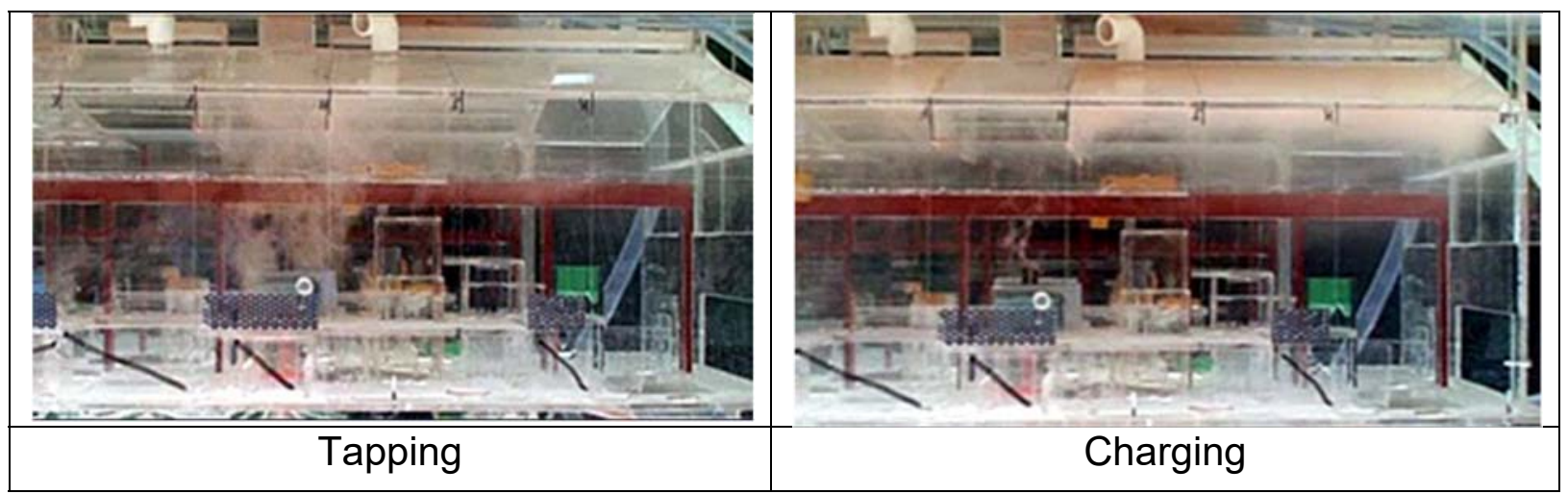

Figure 6. Test \# 9.

The introduction of the 15-20 mph wind blowing through the scrap transfer door reduces the efficiency of the SEC system even more. The results of the Test $9 \mathrm{~B}$ are similar to Test 9 but with even less capture performance of the canopy hood. Fume escapes through the roof gravity ventilators during tapping and charging and disperses within the furnace aisle. 


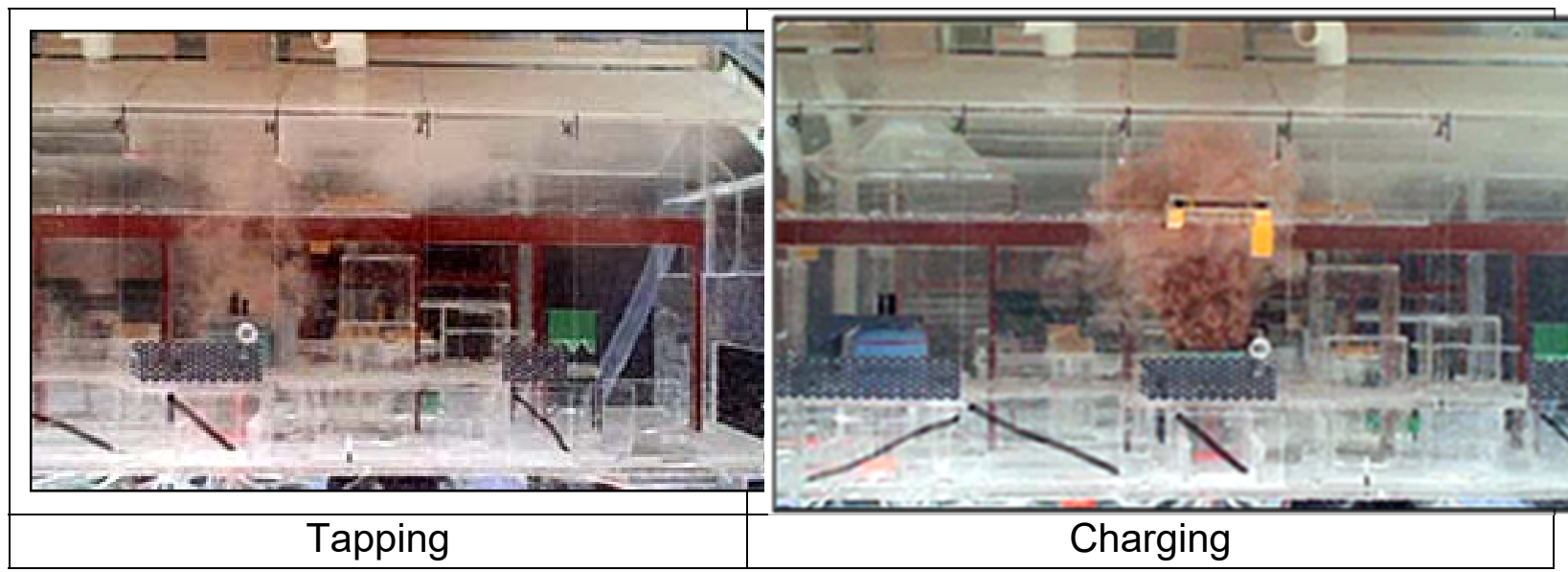

Figure 7. Test \# 9B.

$\mathrm{BCl}$ proposed a different approach to solve the problems with building ventilation. The existing meltshop building had an open layout with no partition walls between the furnace and caster aisles and, therefore, the emission control system is ventilating the entire building. One of the important criteria for sizing the ventilation system is an updraft velocity or the velocity of the air rising from the lower openings to the roof offtakes.

The entire meltshop area is about 82,683 sq. $\mathrm{ft}$ (Figure 8 below). The existing emission control system is capable of evacuating 700,000 ACFM through the roof exhaust. The building updraft velocity is:

\section{0,000 ACFM / 82,683 $\mathrm{ft}^{2}=8.46 \mathrm{ft} / \mathrm{min}$}

The statistics collected by $\mathrm{BCl}$ for many years shows that in order to achieve good building ventilation the updraft velocity should be about $50 \mathrm{ft} / \mathrm{min}$. This number can be lower due to the specifics of the building geometry and the equipment layout. According to the equation shown above the building ventilation can be improved either by increasing the overall capacity of the emission control system or to reduce the meltshop area ventilated by the emission control system.

The increase of the emission control system capacity in order to achieve an updraft velocity high enough to properly ventilate the building is extremely expensive and, therefore, it was decided to minimize the area of the meltshop building by installing a partition wall on column line 6 across the entire meltshop building from the operating floor up to the roof as shown on the Figure 9 below.

The enclosed meltshop area with the proposed partition wall is $28,980 \mathrm{sq}$. $\mathrm{ft}$. The updraft velocity becomes:

\section{0,000 ACFM / 28,980 ft² $=24.15 \mathrm{ft} / \mathrm{min}$}

Or about 3 times higher than it was before. 


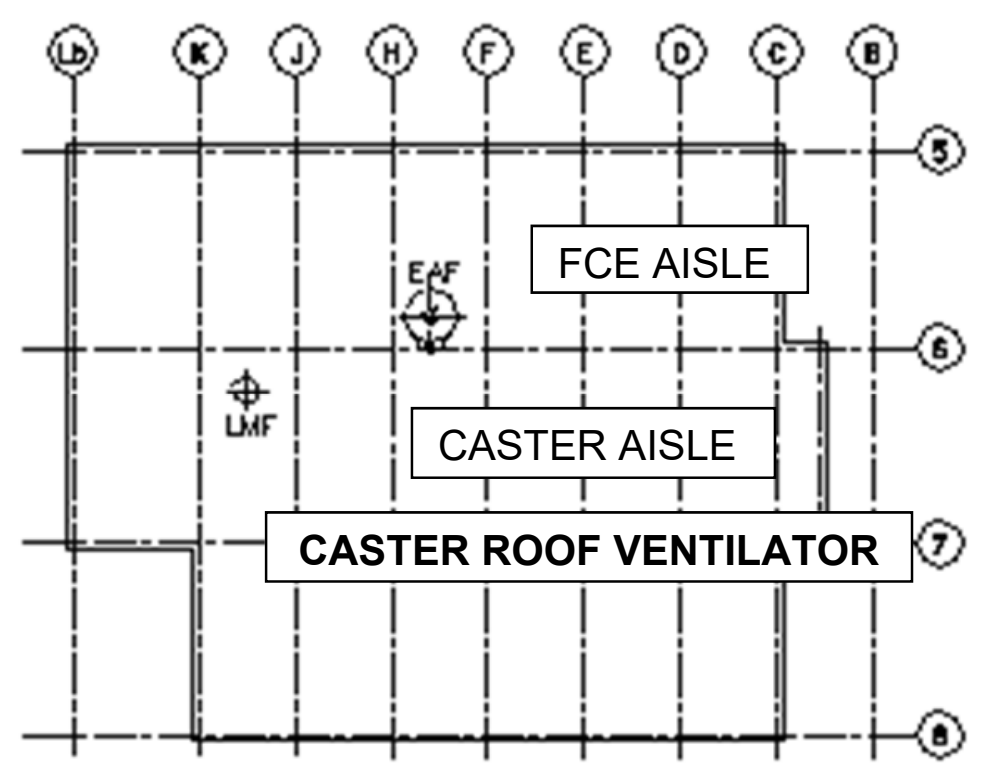

Figure 8. Existing building layout.

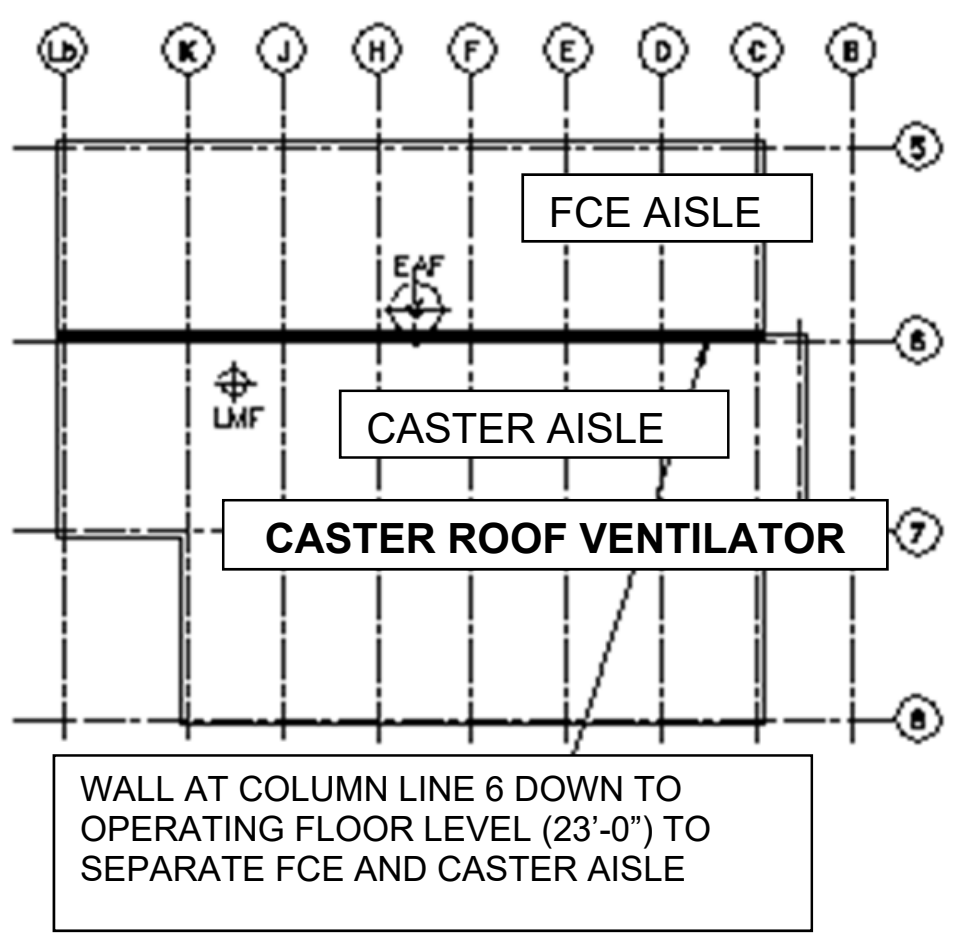

Figure 9. Modified building layout.

$\mathrm{BCl}$ run a series of the tests in order to simulate a step by step effect of the proposed modifications based on the approach described above. 


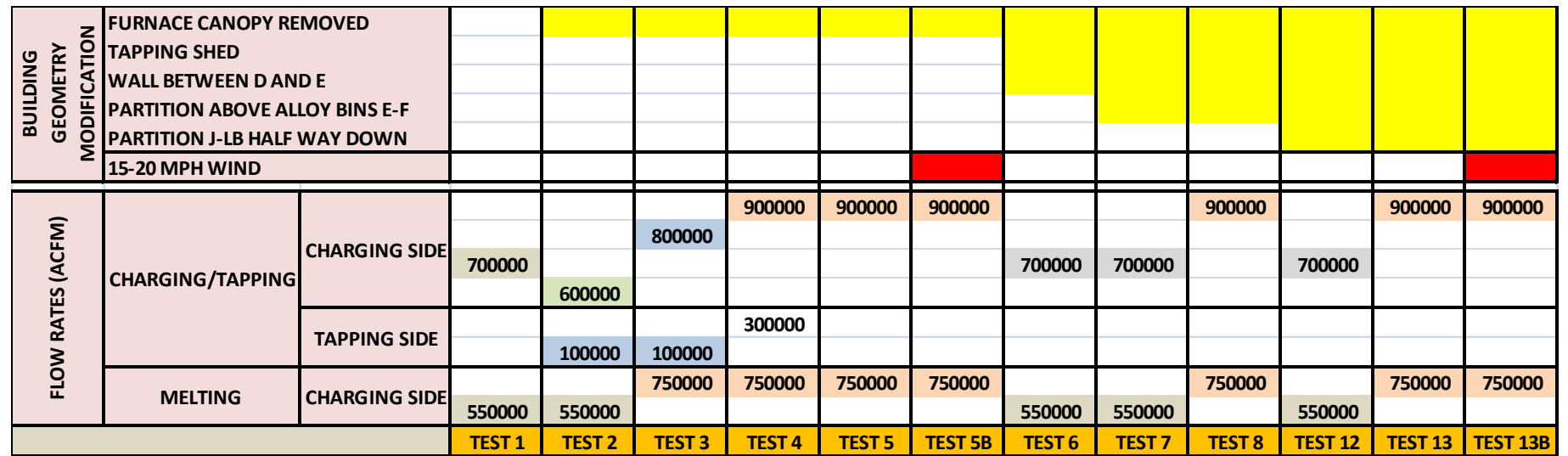

Table II. Test sequence for FDM study.

The Table II above shows the sequence of tests and the modifications introduced during each test. The test results were compiled together into the decision matrix with the risk assessment for each tested configuration (see Table III below).

\begin{tabular}{|c|c|c|c|c|c|c|c|c|c|c|c|c|c|}
\hline \multirow{3}{*}{ TEST \# } & \multirow{3}{*}{$\begin{array}{l}\text { MODE OF } \\
\text { OPERATION }\end{array}$} & \multicolumn{4}{|c|}{ EXHAUST FLOW RATE } & \multicolumn{3}{|c|}{ DOORS } & \multirow{3}{*}{ WIND } & \multirow{3}{*}{$\begin{array}{l}\text { TOTAL B/H } \\
\text { CAPACITY }\end{array}$} & \multirow{3}{*}{ REQIRED MODIFICATIONS } & \multirow{3}{*}{\begin{tabular}{c|} 
OPACITY \\
THROUGH CASTER \\
AISLE ROOF \\
VENTILATORS
\end{tabular}} & \multirow{3}{*}{ RISK LEVEL } \\
\hline & & \multirow[b]{2}{*}{ DEC } & \multicolumn{2}{|c|}{ CANOPY HOOD } & \multirow{2}{*}{$\begin{array}{l}\text { FCE AISLE ONLY } \\
\text { NO CANOPY }\end{array}$} & \multirow[b]{2}{*}{ NORTH } & \multirow[b]{2}{*}{ WEST } & \multirow[b]{2}{*}{ EAST } & & & & & \\
\hline & & & FCE AISLE & CASTER AISLE & & & & & & & & & \\
\hline & & ACFM & ACFM & ACFM & ACFM & & & & MPH & ACFM & & & \\
\hline \multirow{3}{*}{1} & MELTING & 150,000 & 550,000 & 0 & N/A & OPEN & OPEN & OPEN & 0.0 & 700,000 & & & \\
\hline & CHARGING & 0 & 700,000 & 0 & N/A & OPEN & OPEN & OPEN & 0.0 & 700,000 & EXISIING GEOMIEIRY + EXISIING EXAAUST FLOW & YES & HIGH \\
\hline & TAPPING & 0 & 600,000 & 100,000 & N/A & OPEN & OPEN & OPEN & 0.0 & 700,000 & & & \\
\hline & MELTING & 150,000 & 450,000 & 100,000 & N/A & OPEN & OPEN & OPEN & 0.0 & 700,000 & & & \\
\hline 2 & CHARGING & 0 & 600,000 & 100,000 & N/A & OPEN & OPEN & OPEN & 0.0 & 700,000 & EXISTING GEOMETRY + EXISTING EXHAUST FLOW & YES & HIGH \\
\hline & TAPPING & 0 & 600,000 & 100,000 & N/A & OPEN & OPEN & OPEN & 0.0 & 700,000 & & & \\
\hline & MELTING & 150,000 & 750,000 & 0 & N/A & OPEN & OPEN & OPEN & 0.0 & 900,000 & & & \\
\hline 3 & CHARGING & 0 & 800,000 & 100,000 & N/A & OPEN & OPEN & OPEN & 0.0 & 900,000 & EXISTING GEOMETRY + FAN OPTIMIZATION & YES & HIGH \\
\hline & TAPPING & 0 & 800,000 & 100,000 & N/A & OPEN & OPEN & OPEN & 0.0 & 900,000 & & & \\
\hline & MELTING & 150,000 & 750,000 & 0 & N/A & OPEN & OPEN & OPEN & 0.0 & 900,000 & & & \\
\hline 4 & CHARGING & 0 & 900,000 & 300,000 & N/A & OPEN & OPEN & OPEN & 0.0 & $1,200,000$ & EXISTING GEOMETRY + ADDITIONAL B/H CAPACITY & YES & HIGH \\
\hline & TAPPING & 0 & 900,000 & 300,000 & N/A & OPEN & OPEN & OPEN & 0.0 & $1,200,000$ & & & \\
\hline & MELTING & 150,000 & 0 & 0 & 750,000 & OPEN & OPEN & OPEN & 0.0 & 900,000 & & & \\
\hline 5 & CHARGING & 0 & 0 & 0 & 900,000 & OPEN & OPEN & OPEN & 0.0 & 900,000 & REMOVAL OF FURNACE AISLE HOOD + FAN & YES & HIGH \\
\hline & TAPPING & 0 & 0 & 0 & 900,000 & OPEN & OPEN & OPEN & 0.0 & 900,000 & & & \\
\hline & MELTING & 150,000 & 0 & 0 & 750,000 & OPEN & OPEN & OPEN & $15-20$ & 900,000 & & & \\
\hline $5 B$ & CHARGING & & 0 & 0 & 900,000 & OPEN & OPEN & OPEN & $15-20$ & 900,000 & AL OF FURNACE AISLE HOOD + FAN & YES & HIGH \\
\hline & TAPPING & 0 & 0 & 0 & 900,000 & OPEN & OPEN & OPEN & $15-20$ & 900,000 & & & \\
\hline & MELTING & 150,000 & 0 & 0 & 550,000 & OPEN & OPEN & OPEN & 0.0 & 700,000 & & & \\
\hline 6 & CHARGING & 0 & 0 & 0 & 700,000 & OPEN & OPEN & OPEN & 0.0 & 700,000 & ALL ON LINE 6 BETWEEN CRANE GIRDER AND & COMMLEIELY & NO RISK \\
\hline & TAPPING & 0 & 0 & 0 & 700,000 & OPEN & OPEN & OPEN & 0.0 & 700,000 & & & \\
\hline & MELTING & 150,000 & 0 & 0 & 550,000 & OPEN & OPEN & OPEN & $15-20$ & 700,000 & & & \\
\hline 7 & CHARGING & 0 & 0 & 0 & 700,000 & OPEN & OPEN & OPEN & $15-20$ & 700,000 & OPERATING FIOOR + TAPPING ENGLOSURE & YES & HIGH \\
\hline & TAPPING & 0 & 0 & 0 & 700,000 & OPEN & OPEN & OPEN & $15-20$ & 700,000 & OPERATING FLOOR + TAPPING ENCLOSURE & & \\
\hline & MELTING & 150,000 & 0 & 0 & 750,000 & OPEN & OPEN & OPEN & $15-20$ & 900,000 & WALL ON LINE 6 BETWEEN CRANE GIRDER AND & & \\
\hline 8 & CHARGING & 0 & 0 & 0 & 900,000 & OPEN & OPEN & OPEN & $15-20$ & 900,000 & OPERATING FLOOR + TAPPING ENCLOSURE + & COMPLETELY & NO RISK \\
\hline & TAPPING & 0 & 0 & 0 & 900,000 & OPEN & OPEN & OPEN & $15-20$ & 900,000 & SHEETING ABOVE THE BINS BETWEEN E AND F & & \\
\hline & MELTING & 150,000 & 525,000 & 525,000 & N/A & CLOSED & OPEN & CLOSED & 0.0 & $1,200,000$ & WPGC HOOD WITH TWO OFF-TAKES (TAPPING SIDE & & \\
\hline 9 & CHARGING & 0 & 600,000 & 600,000 & N/A & CLOSED & OPEN & CLOSED & 0.0 & $1,200,000$ & AND FURNACE SIDE), NO WALLS BELOW CRANE & NARGINAL & MODERATE \\
\hline & TAPPING & 0 & 600,000 & 600,000 & N/A & CLOSED & OPEN & CLOSED & 0.0 & $1,200,000$ & RUNWAY & MARGINAL & \\
\hline & MELTING & 150,000 & 525,000 & 525,000 & N/A & CLOSED & OPEN & CLOSED & $15-20$ & $1,200,000$ & WPGC HOOD WITH TWO OFF-TAKES (TAPPING SIDE & & \\
\hline $9 \mathrm{~B}$ & CHARGING & 0 & 600,000 & 600,000 & N/A & CLOSED & OPEN & CLOSED & $15-20$ & $1,200,000$ & AND FURNACE SIDE), NO WALLS BELOW CRANE & YES & HIGH \\
\hline & TAPPING & 0 & 600,000 & 600,000 & N/A & CLOSED & OPEN & CLOSED & $15-20$ & $1,200,000$ & RUNWAY & & \\
\hline & MELTING & 150,000 & 500,000 & 250,000 & N/A & CLOSED & OPEN & CLOSED & $15-20$ & 900,000 & WPGC HOOD WITH TWO OFF-TAKES (TAPPING SIDE & & \\
\hline 10 & CHARGING & 0 & 700,000 & 200,000 & N/A & CLOSED & OPEN & CLOSED & $15-20$ & 900,000 & AND FURNACE SIDE), NO WALLS BELOW CRANE & YES & HIGH \\
\hline & TAPPING & 0 & 700,000 & 200,000 & N/A & CLOSED & OPEN & CLOSED & $15-20$ & 900,000 & RUNWAY & & \\
\hline & MELTING & 150,000 & 0 & 0 & 550,000 & OPEN & OPEN & OPEN & $15-20$ & 150,000 & & & \\
\hline 11 & CHARGING & 0 & 0 & 0 & 700,000 & OPEN & OPEN & OPEN & $15-20$ & 0 & TOP OE CRANEATHNE + CONSTEELECE & EUIMINATED & NO RISK \\
\hline & TAPPING & 0 & 0 & 0 & 700,000 & OPEN & OPEN & OPEN & $15-20$ & 0 & & & \\
\hline & MELTING & 150,000 & 0 & 0 & 550,000 & OPEN & OPEN & OPEN & 0.0 & 700,000 & WALL ON LINE 6 BETWEEN CRANE GIRDER AND & & \\
\hline 12 & CHARGING & 0 & 0 & 0 & 700,000 & OPEN & OPEN & OPEN & 0.0 & 700,000 & OPERATING FLOOR (LINE J THRU LB HALF WAY & COMPLETELY & NO RISK \\
\hline & TAPPING & 0 & 0 & 0 & 700,000 & OPEN & OPEN & OPEN & 0.0 & 700,000 & DOWN) + TAPPING ENCLOSURE & & \\
\hline & MELTING & 150,000 & 0 & 0 & 750,000 & OPEN & OPEN & OPEN & 0.0 & 900,000 & WALL ON LINE 6 BETWEEN CRANE GIRDER AND & & \\
\hline 13 & CHARGING & 0 & 0 & 0 & 900,000 & OPEN & OPEN & OPEN & 0.0 & 900,000 & OPERATING FLOOR (LINE J THRU LB HALF WAY & EUIMINATED & NO RISK \\
\hline & TAPPING & 0 & 0 & 0 & 900,000 & OPEN & OPEN & OPEN & 0.0 & 900,000 & DOWN) + TAPPING ENCLOSURE & & \\
\hline & MELTING & 150,000 & 0 & 0 & 550,000 & OPEN & OPEN & OPEN & $15-20$ & 150,000 & & & \\
\hline $13 B$ & CHARGING & 0 & 0 & 0 & 700,000 & OPEN & OPEN & OPEN & $15-20$ & 0 & ITION WALL AT LINE 6 + CURTAIN WALL TO THE & ELY & NO RISK \\
\hline & TAPPING & 0 & 0 & 0 & 700,000 & OPEN & OPEN & OPEN & $15-20$ & 0 & & & \\
\hline
\end{tabular}

Table III. Decision matrix. 
The FDM study shows that removing the canopy hood sheeting below the roof and installation of the partition wall on column line 6 even with the existing capacity of the emission control system greatly improves the building ventilation.

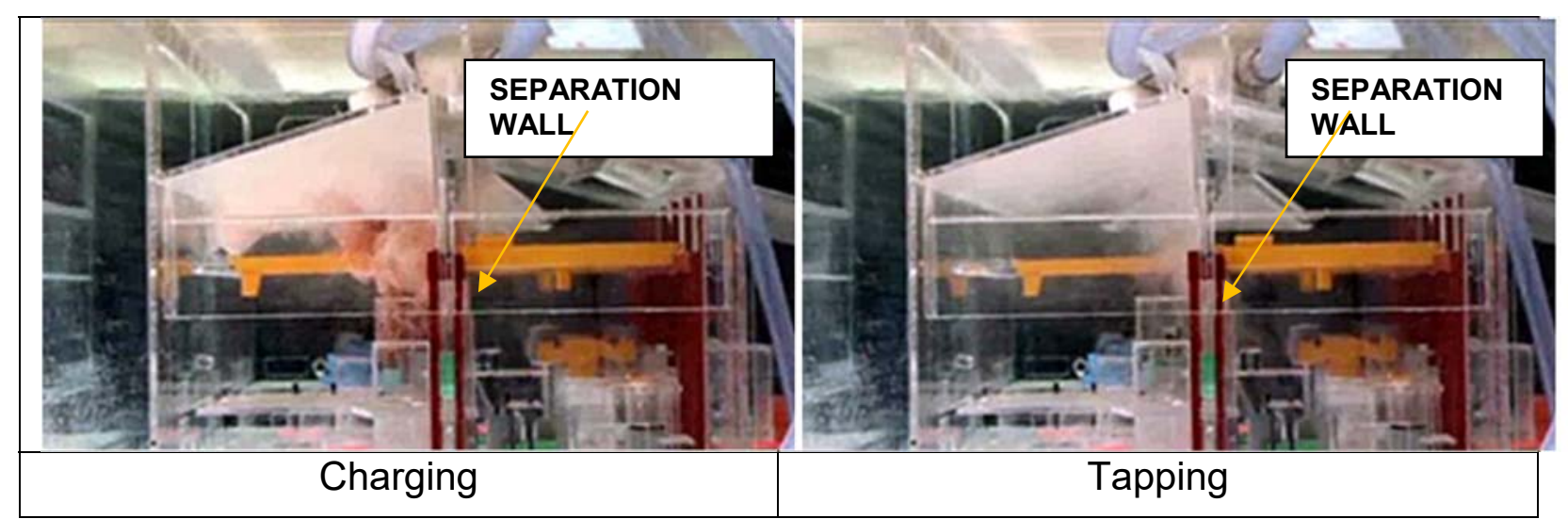

Figure 10. Test \#6: wall along line 6 and canopy hood sheeting removed.

The fume stays contained within the furnace aisle and above the crane runway at all times. However, this configuration does not perform satisfactory with the 15-20 mph wind blowing into the wide open scrap door at the west side of the building. In order to reduce the dramatic effect of the wind the emission control capacity needs to be increased to 900,000 ACFM, which is feasible to achieve by improving the performance of the main I.D. fans. The results of the test are shown on the Figure 11 below.

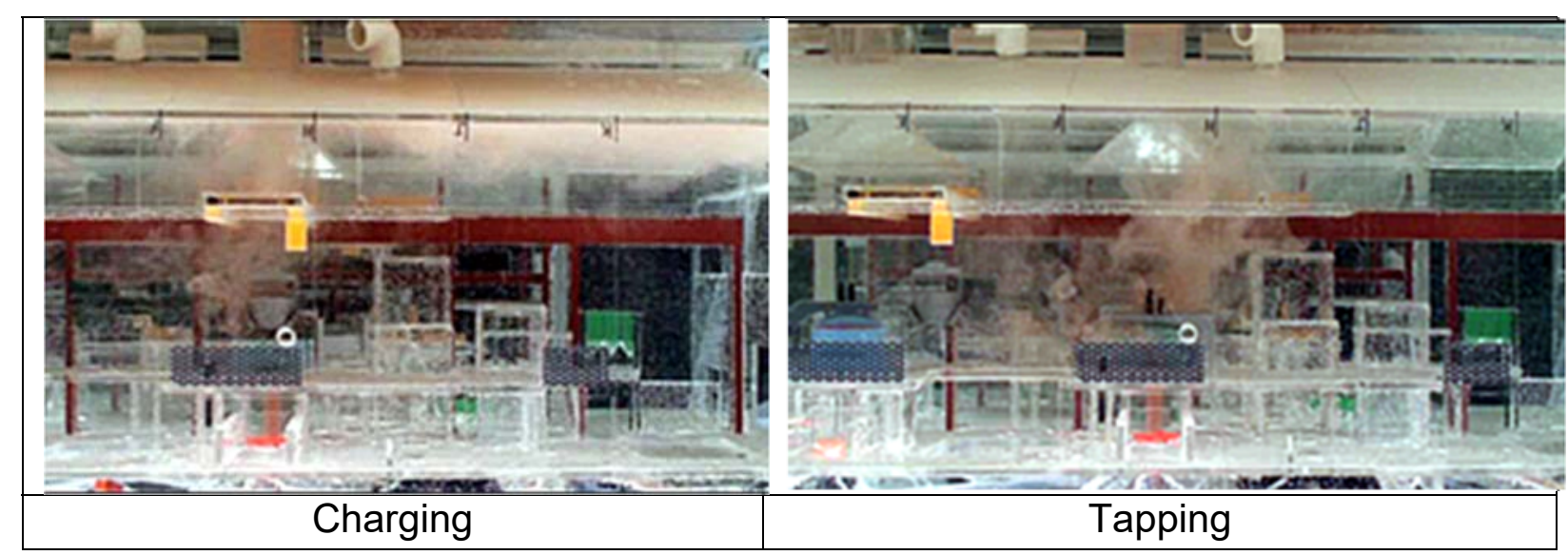

Figure 11. Test \#8: same as test 6 but with 900,000 ACFM roof exhaust.

The existing canopy hood ductwork is too small for the increased flow rate and the increased system pressure drop due to this reason would not allow the system to run at full capacity. That is why it was decided to run an additional set of tests in order to examine the possibility of using the existing hood \#1 off-take above the tundish tilting stand as an additional scavenger exhaust. The Figure 12 below shows the test sequence for this study. 


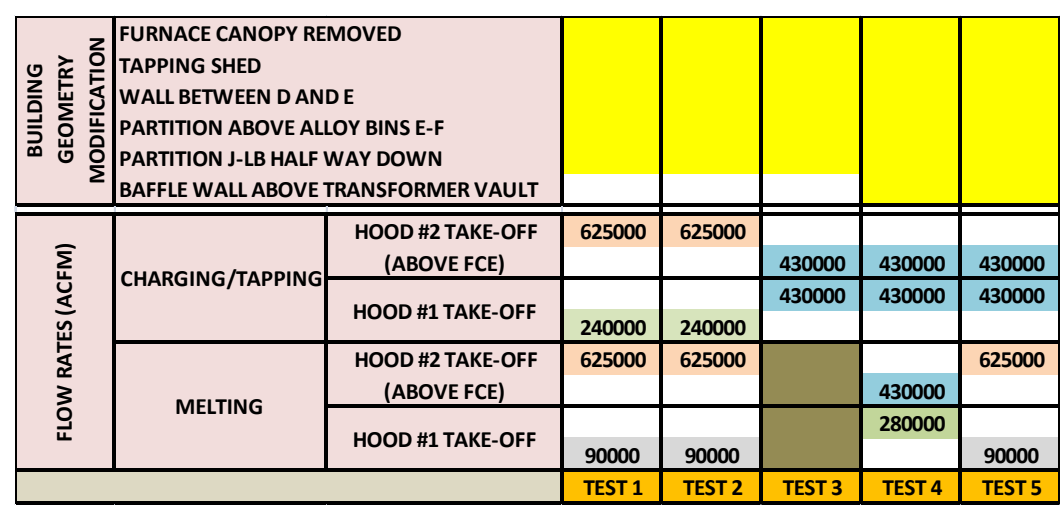

Table IV. Test sequence for an additional FDM study.

After testing a series of exhaust flow combinations, it was determined that Test 5 is the best overall solution for using the existing duct work and maximum flow rates. The test showed that by using the maximum exhaust flow rate of 625,000 ACFM on canopy hood \#2 during melting will reduce the overall emissions build-up within the meltshop and prevent melting fume from mixing with clean warm air. During tapping and charging, the maximum exhaust flow rate of 860,000 ACFM should be split between canopy Hood 2 and canopy Hood 1 according to the Table IV above, which provides an optimum capture and overall recovery of the meltshop.

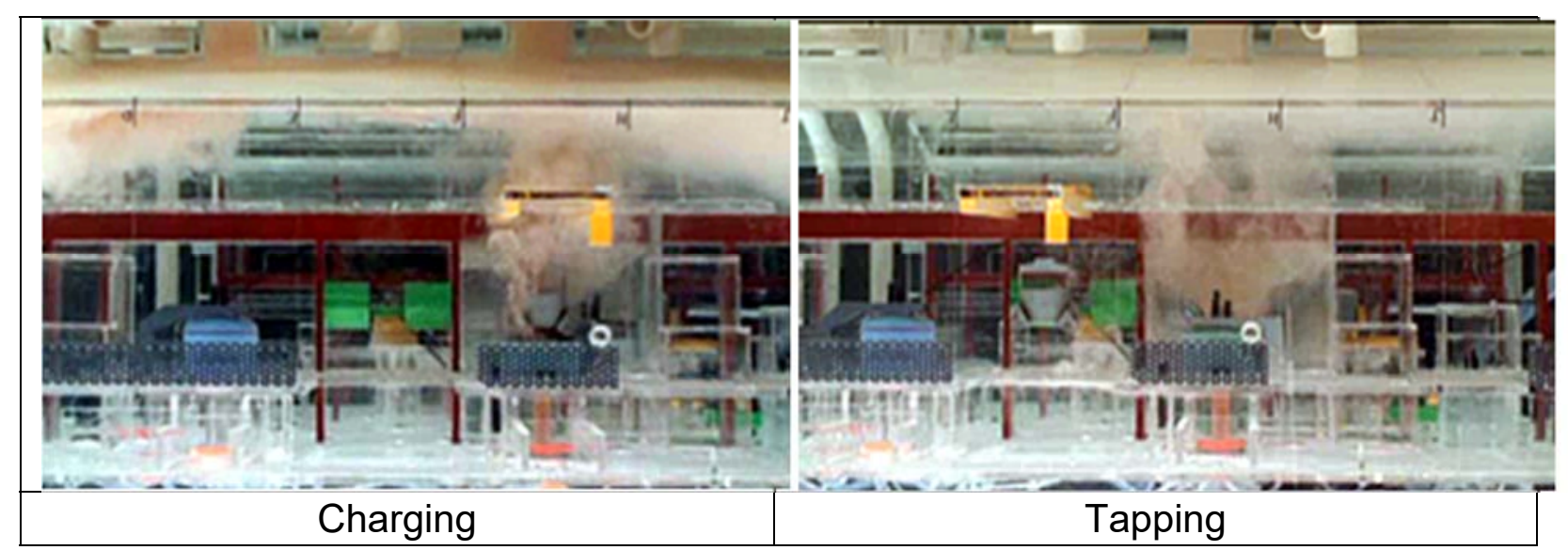

Figure 12. Test \#5 additional FDM study.

\section{Implementation}

However, the implementation of the modifications proposed as the result of the FDM study raised the following challenges:

1. The installation of the tapping shed between the column lines $F$ and $H$.

2. Gastight sealing of the partition wall along column line 6 .

The space in front of the furnace is very congested due to close proximity of the furnace to the caster and the LMF. A tapping shed should be shaped in order to provide enough clearance for the ladle passage from the caster side and at the same time to provide enough space for the furnace roof in the open position and to cover the ladle positioned for tapping. The final configuration of the shed is shown on Figure 13. 


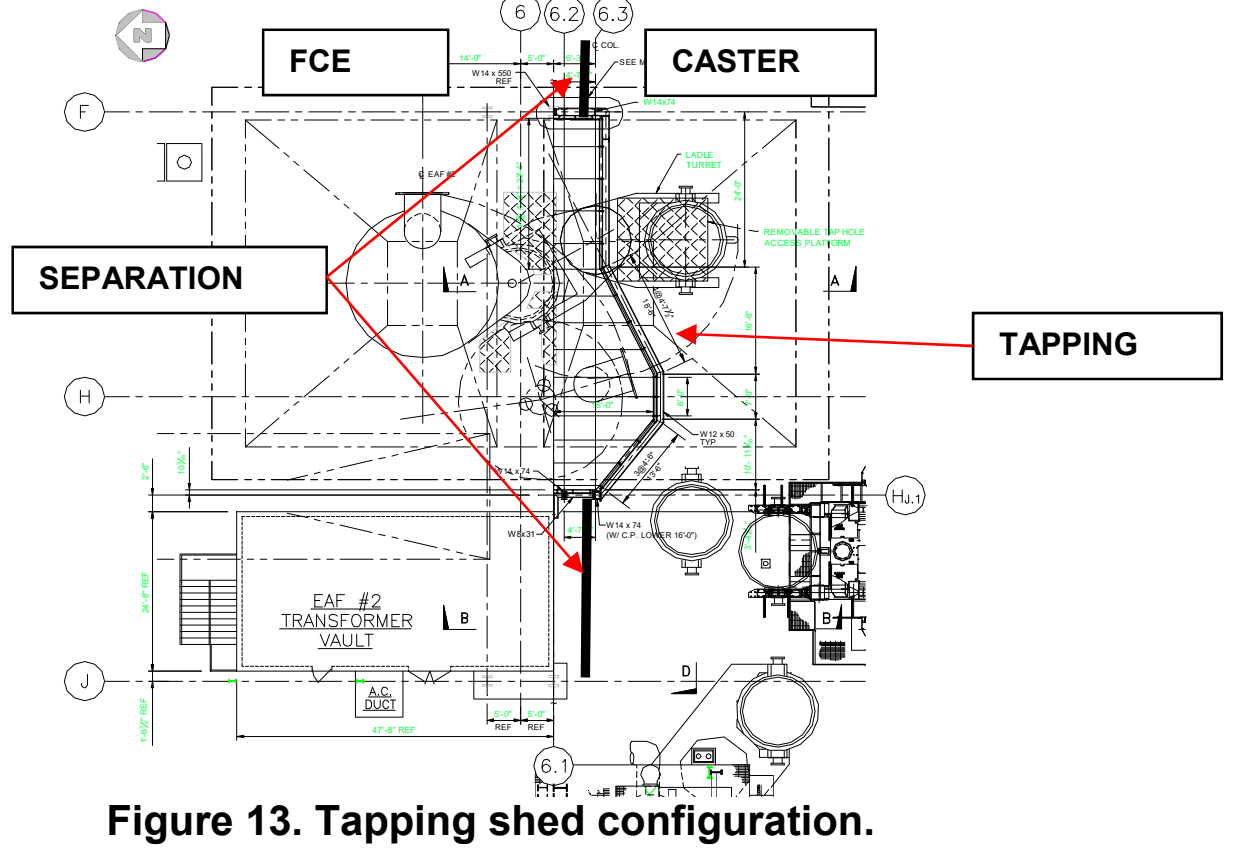

The tapping shed could not have any support columns between column lines $\mathrm{F}$ and $\mathrm{HJ} 1$ due to the ladle turret and due to necessity to maintain the clearance for the slag removal front end loader and should be spanned across 59'. At the same time the shed structure should be strong enough to withstand an occasional explosion. The shed structure was designed and analyzed using STAAD-PRO software in order to achieve the required structural integrity with a minimum load on the existing structure. The special combination of KAOWOOL blanket, KAOWOOL HS45 board and 3/16" plate was used for the tapping shed panel design in order to enable them to withstand a high temperature without warping and to withstand the explosion pressure load. The existing building structure including the crane girder bottom flange were lined with rigid heat insulation boards for radiation protection.

The panels are mounted on the inside the tapping shed and form a nice smooth surface to eliminate an excessive dust build up.

The tapping shed was installed in summer 2011 and in November 2011 the plant pass the compliance test. The cost for the tapping shed installation, installation of the wall on line 6 and sealing the existing sheeting was close to $\$ 2,000,000$.-

The installation of the partition wall significantly reduced the noise level in the caster aisle, which is an additional benefit. An increase in ambient temperatures at the EBT service area was perceived and corrected with the installation of a cooling system for the operators. 


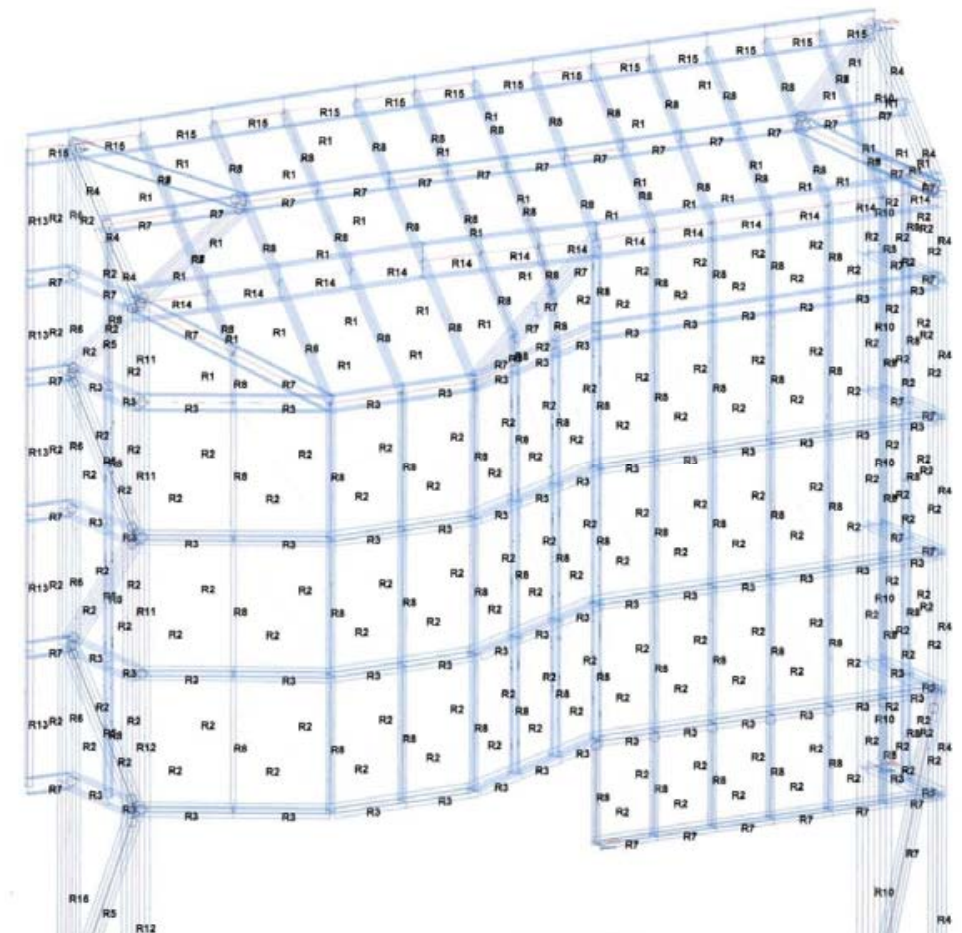

Figure 14. Tapping shed construction.

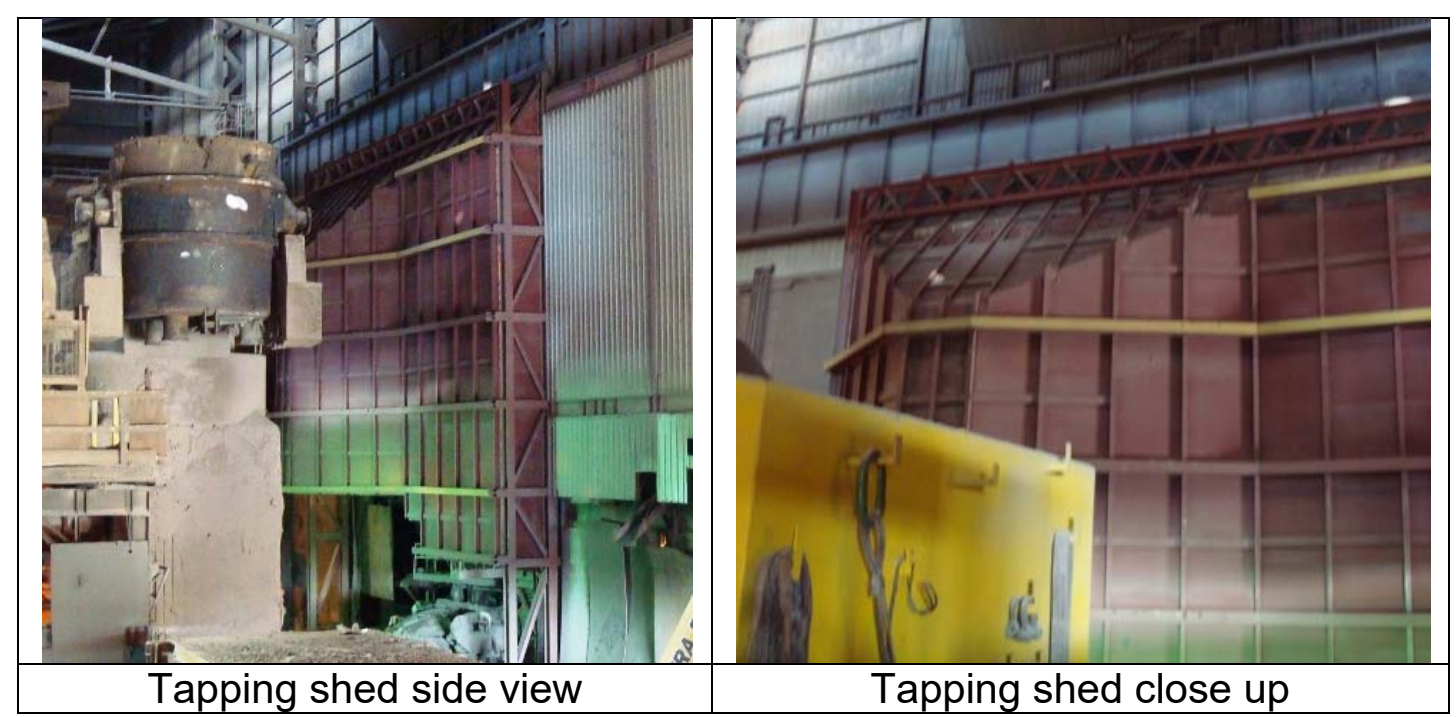

Figure 15. Tapping shed. 


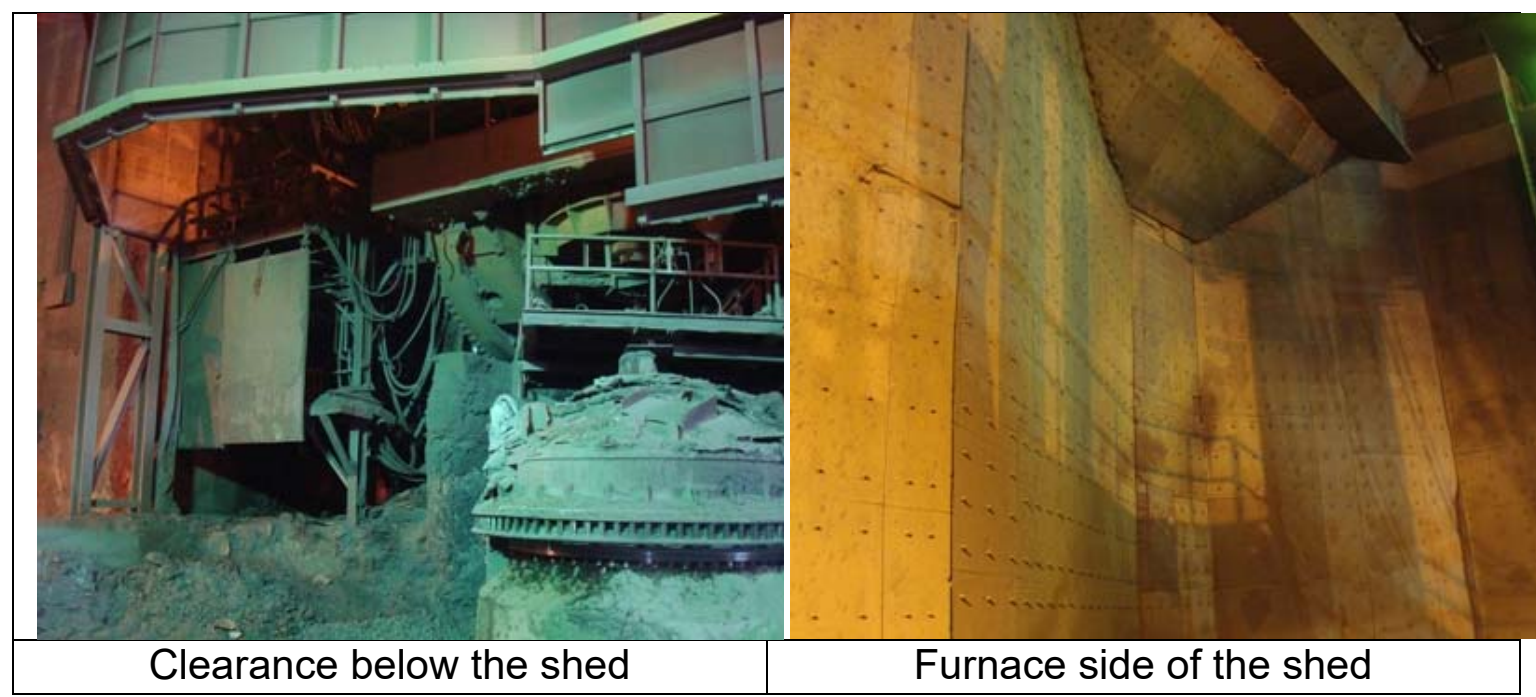

Figure 16. Tapping shed details.

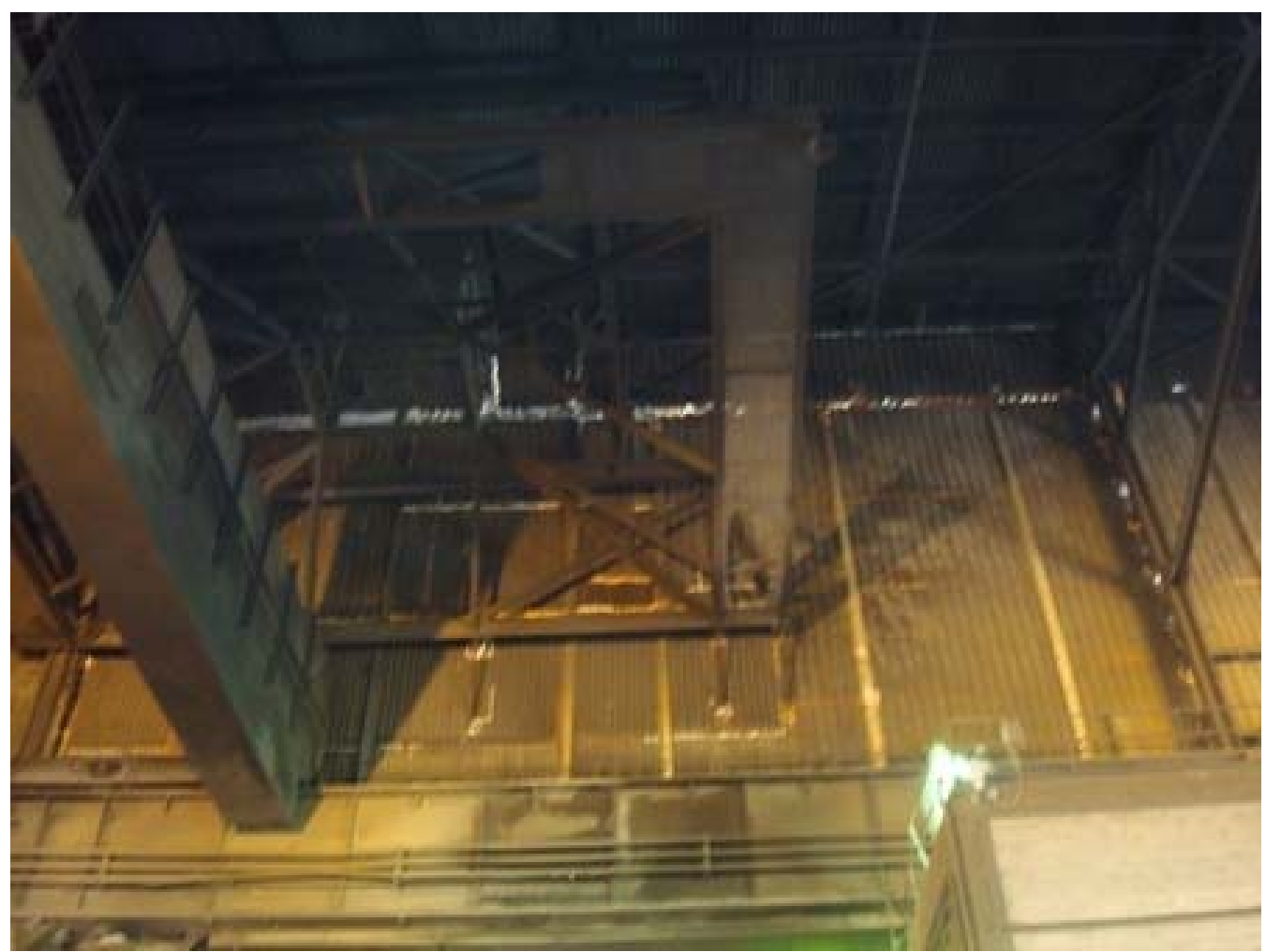

Figure 17. Existing sheeting sealed with high temperature sealant.

\section{REFERENCES}

1 Industrial Ventilation, A Manual of Recommended Practice for Design, $27^{\text {th }}$ Edition by ACGIH, Chapter 2

2 Air Pollution Engineering Manual, $2^{\text {nd }}$ Edition, by Air \& Waste Management Association, pp 579-587. 